\title{
A Substitute Technology for the Currently Applied Bridge-Like Water Intake along the River Nile in Egypt
}

\author{
Dr. Nasr Tawfik Hassan Hekal ${ }^{1}$, Dr. Reda Mohammed Ali Hassan ${ }^{2}$ \\ ${ }^{1}$ Ass., Professor at Nile Research Institute, National Water Research Center, \\ Email:nasrhekal@gmail.com \\ ${ }^{2}$ Ass., Professor at Coastal Research Institute, National Water Research Center, \\ E-mail:Redamah2010@gmail.com
}

\begin{abstract}
Bridge-like intakes are structures extended into open channels carrying suction pipes to reach out to sufficient water depths that can secure permanent abstraction. Such intakes have been found to suffer problems that threaten their performances. The present study aims to highlight these problems and introduce a new technology as a substitute solution. Three problems could be identified by continuous field surveys and monitoring. First, the sediment accumulation at the suction pipe inlet clogs the strainer holes and obstructs water abstraction. Second, the offshore water surface recession due to water stage fluctuation or sediment accumulation causes water surface to be inaccessible to the pipe inlet. Third, the stationary inlet position aggravates the other two problems. A case study of a bridge-like intake at El Koraymat area, south of Cairo, along the Nile eastern bank was introduced to clarify these problems. The intake was found to suffer annual sediment accumulations of about $14000 \mathrm{~m}^{3}$ which resulted in water recession and abstraction interruption. An alternative solution was proposed. The solution concept depends on making the pipe inlet position moveable so that it can mitigate and reduce the occurrence of sediment accumulation and water recession. The tower crane technology was proposed to accomplish this concept.
\end{abstract}

Keywords: Water Intakes; Sedimentation; Water Surface Recession; Tower Crane Technology.

\section{INTRODUCTION}

The task of an open channel intake structure is to abstract water necessary for multiple daily life purposes and activities. If the intake fails to perform this job due to any problem, it might result in the disruption of different basic water-dependent life aspects. In fact, there is a variety of current intake structure technologies already adopted in practice to abstract and divert water from open channels. They have been all invented to cope with the different field conditions encountered in field such as topography, channel morphology, water stage fluctuation. They have been found to undergo different problems that

Received:19 Septamber, 2020, Accepted:6 February, 2021 require high running cost (operation \& maintenance). However, it has been found that they have some problems in common that affect their operational performance efficiency.

Brikké and Bredero [1] classified the intake structure technologies (most commonly found in developing countries) according to the different water sources available as shown in Table 1. There is another intake structure that is already in use but was not mentioned in the classification. It is the bridge-like intake type that is already applied in big numbers along the River Nile in Egypt. It is also provided in the table. 
As the present study is interested in one of the intakes (the bridge-like intake) constructed on open channel banks, the intake technologies that depend on surface water as a source are introduced below along with their potential problems. They are established along the River Nile Banks in Egypt and suffer the sedimentation problem as well. Therefore they cannot be used as a substitute for the bridge-like intake.

Table 1: Types of Intake Structures with respect to Water Sources [1]

\begin{tabular}{|c|c|c|c|c|c|}
\hline $\bar{S}$ & Water & \multicolumn{4}{|c|}{ Intake Structure Technology } \\
\hline 1 & 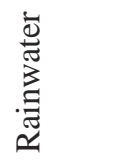 & 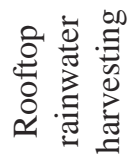 & 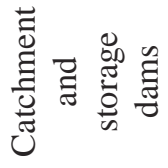 & & \\
\hline 2 & 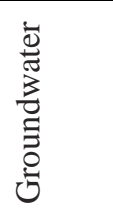 & 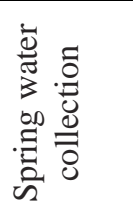 & $\begin{array}{l}\overline{0} \\
3 \\
00 \\
\overline{0}\end{array}$ & $\begin{array}{l}0 \\
\overline{0} \\
3 \\
0 \\
0 \\
\overline{0} \\
\overline{0}\end{array}$ & 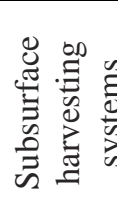 \\
\hline 3 & 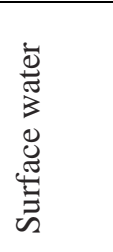 & 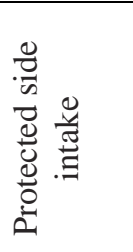 & 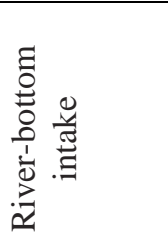 & 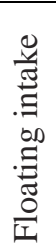 & 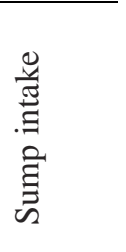 \\
\hline 4 & 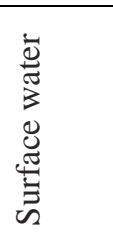 & 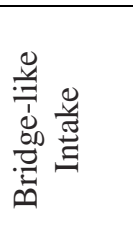 & & & \\
\hline
\end{tabular}

\subsection{Protected Side Intakes}

Lauterjung and Schmidt [2] discussed the technology of a protected side intake. They described it as a stable structure at an open channel bank where surface water can flow into a side channel through a screen that detains debris, scum, and coarse sediment as shown in Fig. 1. This structure is mainly intended to resist floods and reduce sediment deposition problems. It is a side intake having valves or sluices for flushing settling sediment. The intake is always constructed upstream a weir in the open channel that keeps the surface water at the required stage. The weir has a sand trap for depositing sand, and a spillway to dispose of excess water.

\subsubsection{Potential problems}

1. Clogging by silt or debris overtime due to fixed intake position;

2. The side intake system may be undermined by river currents;

3 . The river water may get polluted;

4. It needs regular maintenance and repairs;

5. At low flows very little water is diverted and therefore, this type of intake is not suitable for rivers with great fluctuations inflow.

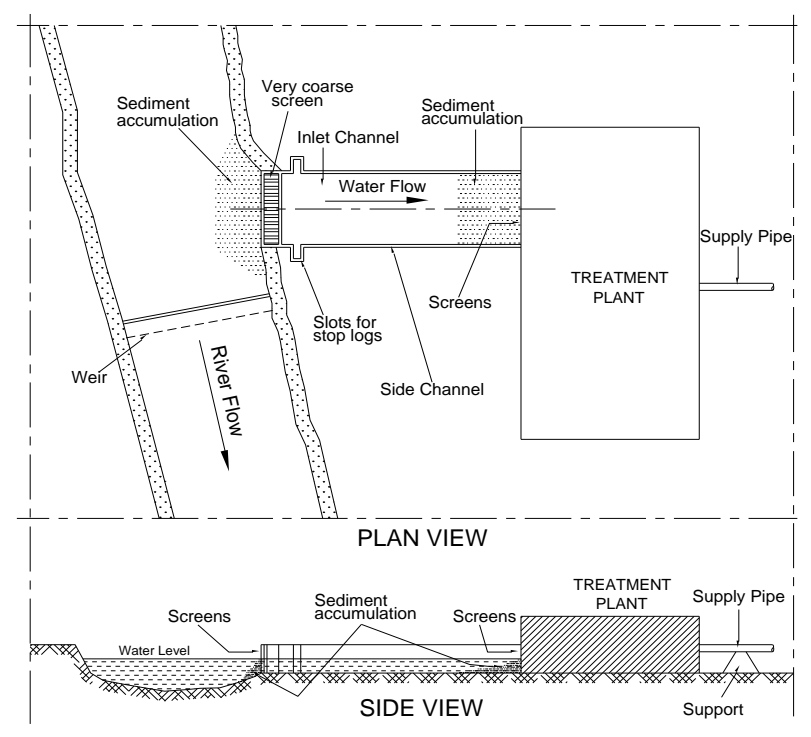

Fig. 1: Protected Side Intake ([2] and redrawn by the authors)

\subsection{River Bottom Intakes}

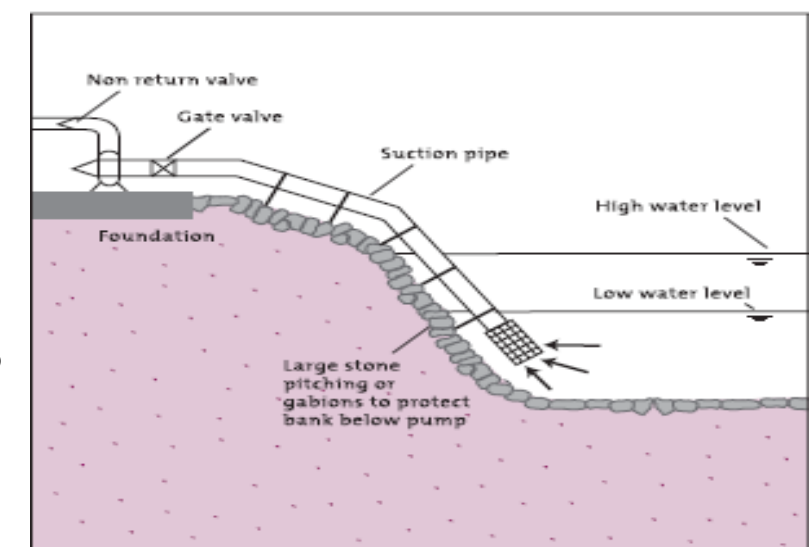

Fig. 2: River Bottom Intake [3] 
Jordan [3] explained the river bottom technology. It is called Tyrolean intake. It is usually used in drinking-water systems to divert water from small rivers and streams where the sediment bed load transport is low. The water is withdrawn through a screen over a canal built into the river bed as shown in Fig. 2. The screen bars are laid in the direction of the water current and sloping downwards, so that coarse material is detained. Water enters a sand trap and then passes a valve and flows by gravity, and may be pumped into the system.

\subsubsection{Potential problems}

1. Clogging by silt or debris overtime due to fixed intake position;

2. Undermining by river currents;

3. The river or stream water may be polluted;

4. During dry season, there may not be enough water in the river or stream to supply all users.

\subsection{Floating Intakes}

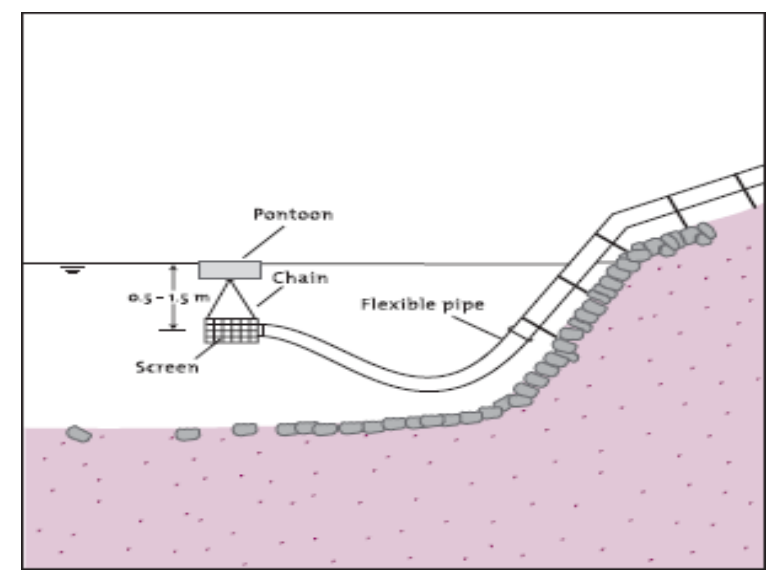

Fig. 3: A Floating Intake [4]

Hofkes and Visscher [4] proposed the floating intake technology. The technology allows water to be abstracted from underneath the surface of an open channel. In this way, it can avoid the heavier silt loads that are usually transported closer to the bed during high flows. The suction pipe inlet is tied just under the water level to a floating pontoon that is moored to the bank or bed of the open channel as shown in Fig. 3. The suction pump itself can be positioned either on the bank or on the pontoon. To establish the pontoon, a steel or wooden frame can be attached to floats of empty oil drums, plastic containers, or sealed steel tubes at least 30 $\mathrm{cm}$ in diameter.

\subsubsection{Potential problems}

1. Floating objects always collide with the floating pontoon and may damage it;

2 . The pipe connectors between the pontoon and the bank wear out;

3. The system is only suitable for small canals; and

4. The freedom of pontoon movement is very limited.

\subsection{Sump Intakes}

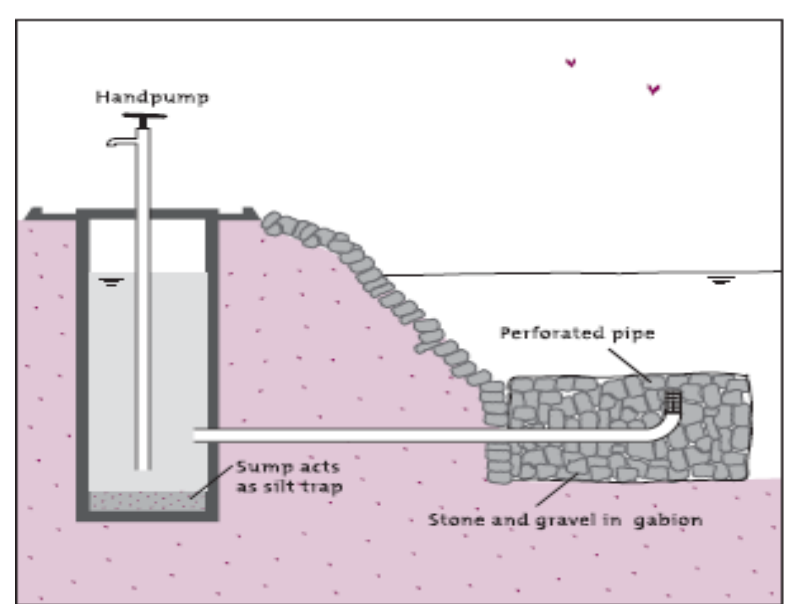

Fig. 4: A Sump Intake [2]

Lauterjung and Schmidt [2] illustrated the technology of a sump intake. Water from an open channel flows under gravity through a pipe placed underwater to a sump where it is elevated and pumped into the initial purification stages of a drinking-water 
system as shown in Fig. 4. The pipe inlet underwater is positioned below the low-water level and is connected to a strainer or screen to disallow clogging by sediment. There is a well that helps suspended sediment load to settle down. For sump maintenance, two sump intakes are sometimes built for one pump.

\subsubsection{Potential problems}

1. Siltation and debris clog the pipe inlet overtime due to fixed intake position;

2. Erosion caused by the open channel current undermines the intake structure and the bank;

3. A sump intake is irrelevant in open channels that are very shallow or have low flow rates.

\subsection{Bridge-like Intakes}

This technology is a bridge built of steel (truss-like) or concrete that starts at the bank of the channel and extends for some distance offshore to reach water particularly during the period of minimum water stages. It is constructed on piers resting on pile caps. The bridge main task is to carry pipes and pumps on the deck to abstract water from the open channel as shown in Fig. 5. The inlet of the suction pipe is submerged into the channel to abstract water. It is covered with a strainer to prevent sediment inflow.

\subsubsection{Potential problems}

1. It is considered an encroachment on the channel watercourse and/or floodplain;

2. Silt and/or debris clogs the pipe inlets;

3. Sediment particles accumulate over time due to fixed inlet position;

4. Scour occurs round the piers supporting the bridge;

5. Recurrent dredging is needed for sediment removal.

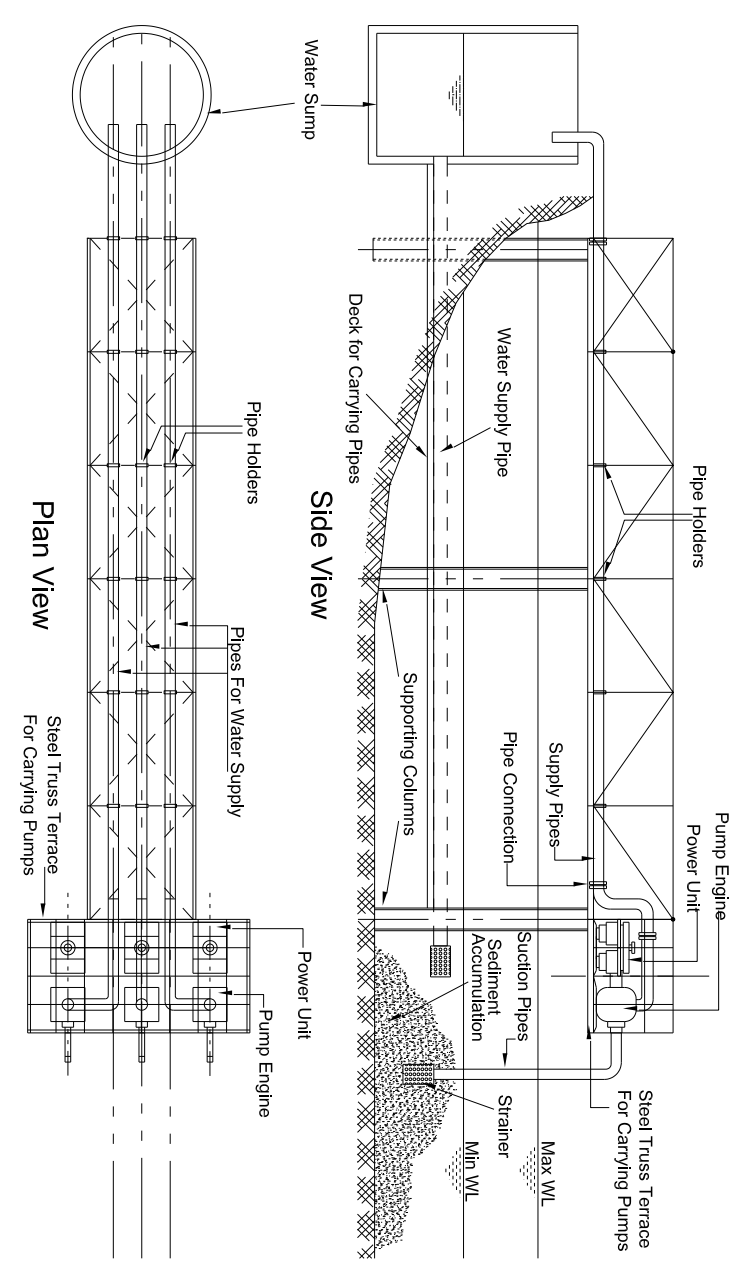

Fig. 5: A bridge-like Intake.

\section{OBJECTIVE}

The present study basically aims to focus on and identify the problems the current bridgelike intake is facing and suffering. The study, also, aims to introduce a practical solution that depends on employing the available tower crane technology to carry the suction pipes instead of the fixed bridge in such a manner that it can avoid and overcome the suffered problems.

\section{STATEMENT OF THE PROBLEMS}

There are three main annoying problems that most current bridge-like intake structures established along the River Nile banks in Egypt suffer. They are: 


\section{Vol. 41, No.2. July 2022}

1. Continuous sediment accumulation (due to intake stationary position) at the inlets of the suction pipes that feed the water (drinking, irrigation, cooling, industrialization) stations. This usually disallows and hinders water flow into the water station and may end in its disruption and further affecting the water-dependent communities and activities. Bosman [5] stated that excessive sedimentation at water intakes on rivers causes interruption in water supply and serious abrasion of pumps with consequent high operating costs;

2. The wide recession of open channel water surface that occurs during low stage periods. It causes the water to be far offshore and inaccessible; and

3. The inability to change the location of the intake in case of encountering the above two problems.

As for the first problem, it is common among almost all the current applied intake technologies mentioned in the previous section. These technologies could not stop or avoid sediment accumulation at all. The only and common solution has been the frequent dredging to remove the accumulations. This solution turned out to be threatening and dangerous to the aquatic life and benthic ecosystems and habitats. Moreover, it is costly and constitutes a heavy burden on the annual operation and maintenance budget of the water station.

As for the second problem, the water stage declines so largely during the period of minimum discharge release that large areas of the floodplains are uncovered as shown in Fig. 6. Water sometimes recedes offshore for distances that reach $100 \mathrm{~m}$ and more. In such a case, it becomes very difficult and more expensive to construct an intake structure to abstract water and ends with the same sedimentation problem around the inlets. Hekal [6] computed the recession distances along reach one of the River Nile and found that they ranged between 1.20 and $812.00 \mathrm{~m}$ along the western river side whereas they ranged between 1.50 and 647.00 along the eastern side. He concluded that the recession distance is an essential governing factor when deciding on the implementation of a bridge-like intake as it affects the project budget.

On the other hand, if a pipe-carrying bridge structure is constructed and extended long to access water, it is considered an encroachment on the river water stream especially, if there is nearby navigation traffic. Moreover, it acts as a barrier (because of its stationary position) that detains debris, scum, and sediments overtime ending in the formation of sediment accumulations around the pipe inlet causing blockage of the water inflow. Also, if pipes are extended under river bed to access water, the filtering holes of the strainers fitted on the inlets get clogged overtime due to the continuous sedimentation resulting from both suction velocity and pipe fixed position.

As for the third one, the choice of a water intake location along the open channel banks in most cases is not an easy or optional task. On the contrary, it is sometimes compulsory. In practice, there are villages alongside the channel water stream still deprived of potable water because of the unavailability of a nearby location for constructing a water plant and its intake. Once finding a location, the people in charge are sometimes obliged to agree for a number of reasons:

- There's no other alternative. The location is the only availability and opportunity; 
- The increasing social pressure of the community to be served;

- It is too difficult to expropriate or confiscate another location to construct the intake and plant premises because of the unavailability of sufficient funding; and

- When the alternative site is very far, it requires the extension of pipes for long distances which, in turn, needs land confiscation for easements (rights of way) and burying the pipes in. Moreover, the conveyance losses become very high and costly.

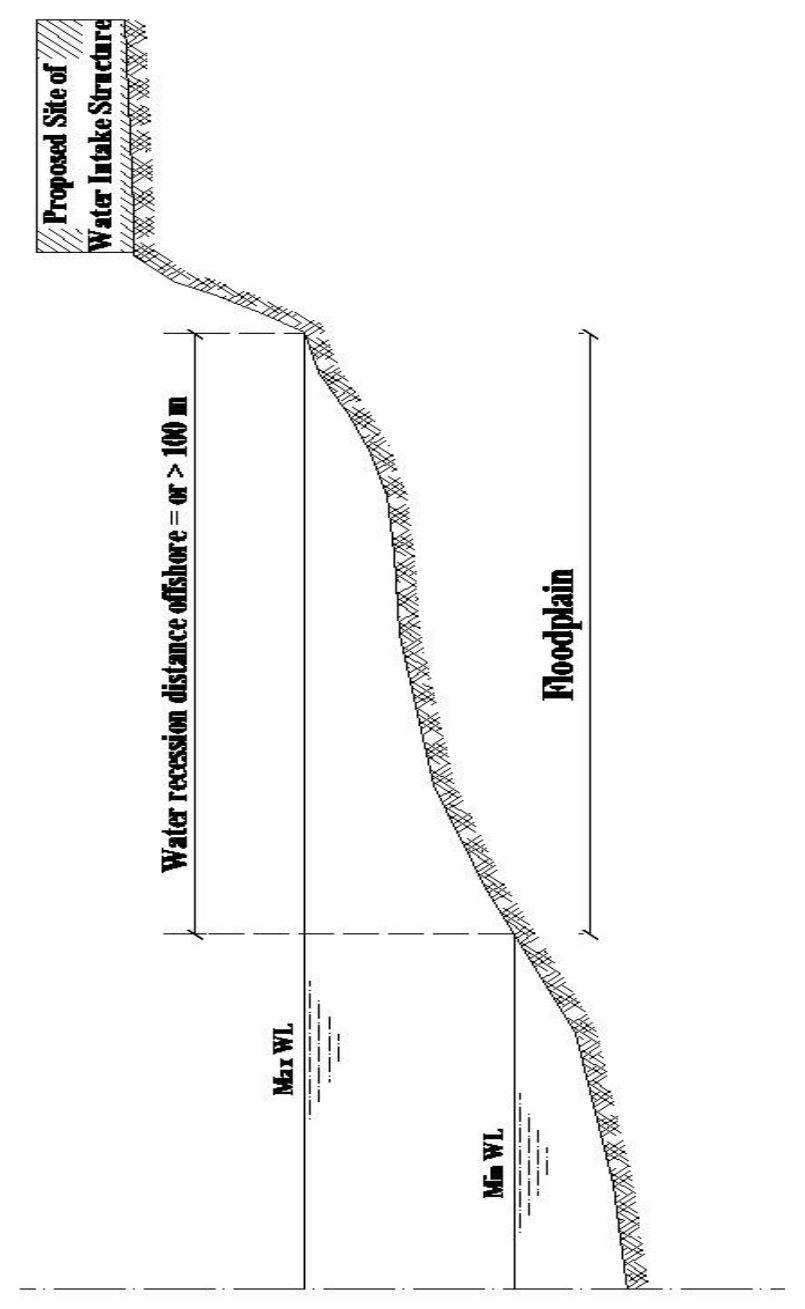

Fig. 6: Surface water recession during low water period (the dry season) [6]

\section{Examples of Bridge-like Intakes Suffering Sediment Deposition within Egypt}

The bridge-like intake technology is extensively applied along the River Nile and its two branches, Damietta and Rosetta in Egypt. It is considered a blatant intervention into the river flow regime. It has been causing the problems mentioned above, especially the sedimentation one. This problem is considered crucial for water pumping stations. According to the Nile Research Institute (NRI) study reports (20002020), there are a big number of intakes suffering from continuous sedimentation. For instance, the intakes of the drinking water plant as at Nida village in Sohaj Governorate, at Greater Cairo drinking water plant, at Luxor drinking water plant, that of Koraymat drinking water plant, at Koraymat power station ...etc. They all have recurrent sediment accumulations round the suction pipe inlets and require riverbed dredging almost annually to provide the water depths necessary for ensuring permanent abstraction. Fig. 7 shows other bridge-like intakes at other locations suffering from severe sedimentation and suction pipe blockage and clogging. They also suffer from interruption of water abstraction during low water discharge periods because of large water recession. 
Vol. 41, No.2. July 2022

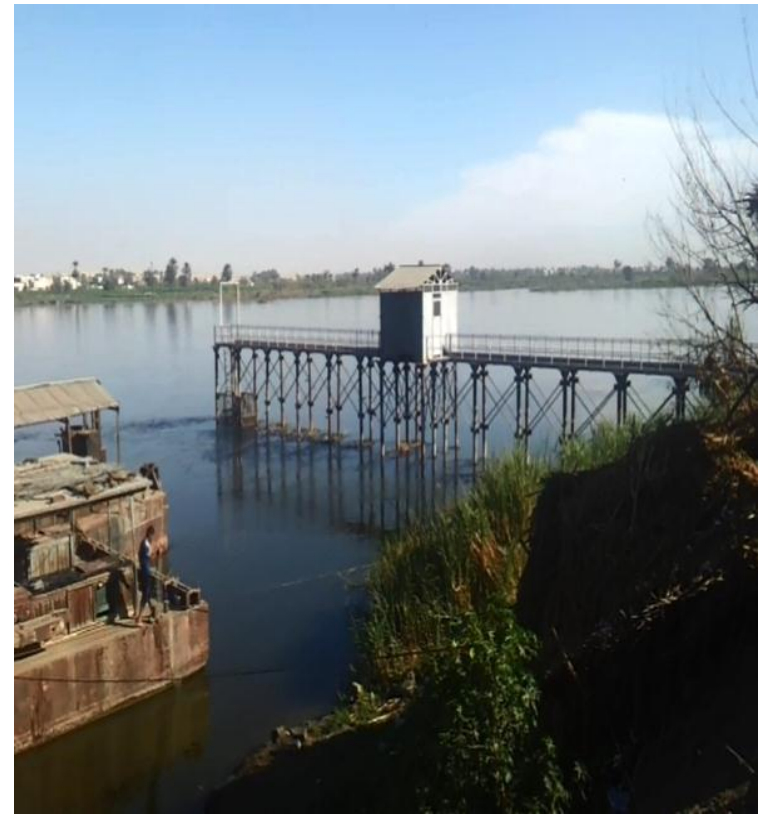

Fig. 7 - A: Abbad Sharona Village - EL Menia 2016

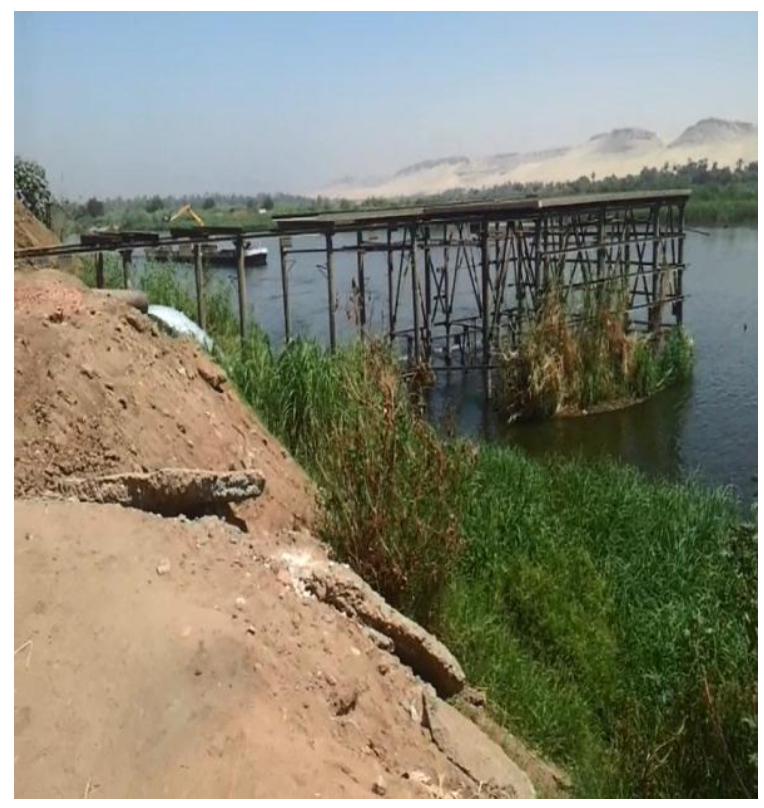

Fig. 7 - B: Dairut Town - Assuit - 2015

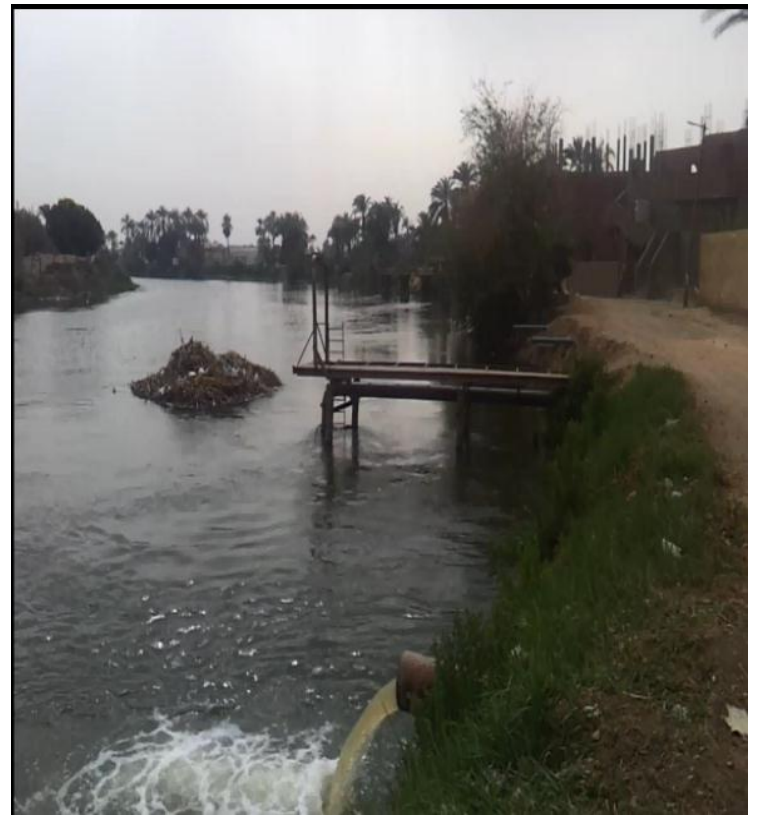

Fig. 7 - C: Edwa Village - Bahr Youssef - El Menia - 2016

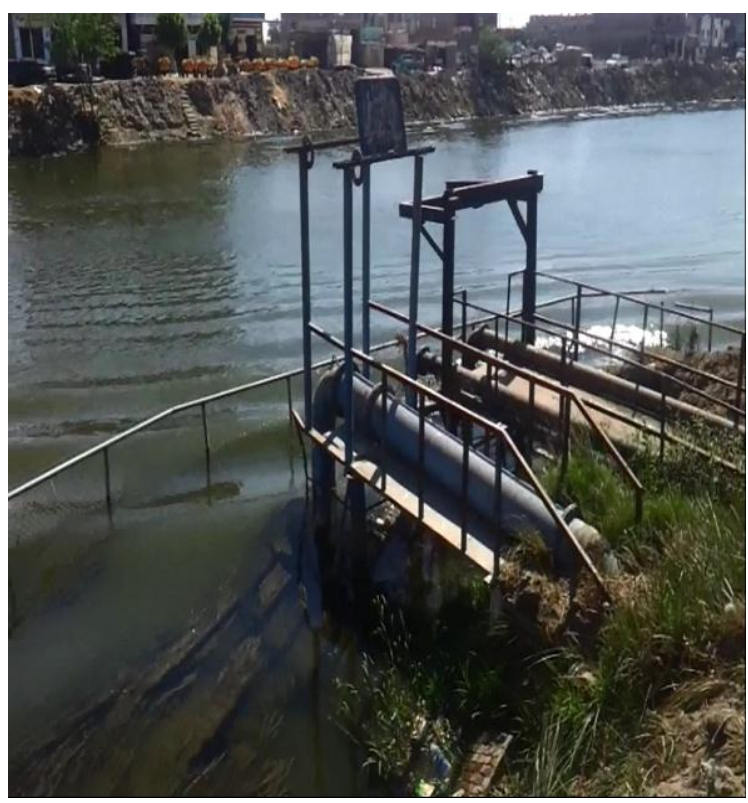

Fig. 7 - D: Mashtool Elsooq - Ismailia Canal $\begin{array}{llll}\text { El Sharqia } & \text { - } & 2017\end{array}$ 


\section{MATERIALS AND METHODS}

\subsection{Case Study}

\subsubsection{Location}

As an illustrative example of the 3 problems mentioned in the problem statement section, the status of the existing bridge-like intake of Koraymat drinking water plant is considered the most representative. It lies within reach (4) of the River Nile at about kilometer 88.470 (cross section centerline of the intake) upstream Roda gauge in Cairo as shown in Fig. 8- a, b, c.

\subsubsection{Field Measurements}

According to the request by the National Authority for Drinking Water \& Sanitary Drainage (NADWSD) in September, 2013 to investigate the problem at the intake, the NRI conducted a field hydrographic survey for data collection. It collected bathymetric data, measured flow velocities, and took samples of river water and bed soil for lab analysis.

\subsubsection{Analysis and Results}

After doing the necessary office analyses, the study revealed that sediment deposition around the inlets of the suction pipes had been occurring. The sediment accumulation at the intake suction pipe inlets had occurred due to their fixed positions. There are strainers (screens) installed on the pipe inlets for stopping sediment load particles or debris from entering the suction pipes. These particles swiftly flocked to the pipe inlets under the suction forces but were not allowed in. Instead, they united together, flocculated, and built up over time in the area surrounding the intake inlets forming a barrier that detained other attracted sediment particles behind. The channel bed started to aggrade due to the detained particles and the sediment accumulations covered the inlets until they prevented water flow into the pipes completely. Consequently, the water receded further offshore. It became inaccessible during minimum \& even maximum water level periods because the intake length had been designed and constructed with a fixed length of about $25.00 \mathrm{~m}$ offshore where the river water flow was accessible at that time as shown in Fig. 9.

\subsubsection{Study Recommendations}

NRI report [7], issued in January, 2014, recommended either to dredge the sediment accumulations around the intake or to look for another location along the river where water depths are available all the year round for ensuring permanent water abstraction.

\subsubsection{Consequent Measures}

Since the intake had been suffering from the problem severely before and a lot of dredging works had been done without consulting the NRI, the NADWSD had to accept the second recommendation. They wanted to avoid and reduce the dredging which was estimated at about $14000 \mathrm{~m}^{3}$ of sediment accumulation annually at the time. It suggested the construction of a new intake at another new place (Fig. 8 - b \& c) about $500 \mathrm{~m}$ downstream the above section where water sufficient depths were available according to NRI study report [7]. Accordingly, the NADWSD planned to allocate more finances to purchase a piece of land to be the new intake location, and to design and construct the new intake structure and to extend supply pipes for a distance of $500 \mathrm{~m}$ long back to the original plant site. Unfortunately, the bridgelike intake type (despite knowing its potential problems) was again decided to be applied at the new proposed site ignoring the possibility of the occurrence of the same problem at future. 
Vol. 41, No.2. July 2022

This case study shows clearly the occurrence of the three problems which the current research is intended to overcome. They are:

1. The occurrence of continuous sediment deposition round the suction pipe inlets due to the intake fixed position;

2. Large water recession due to sediment accumulations that made the river flow inaccessible to the intake inlets during low and high water stages; and

3. Searching for a new intake position along the river where water is available all the year round. This cost the NADWSD a lot of finances to construct the new intake and pay for land expropriation to extend the supply pipes back to the original plant location.

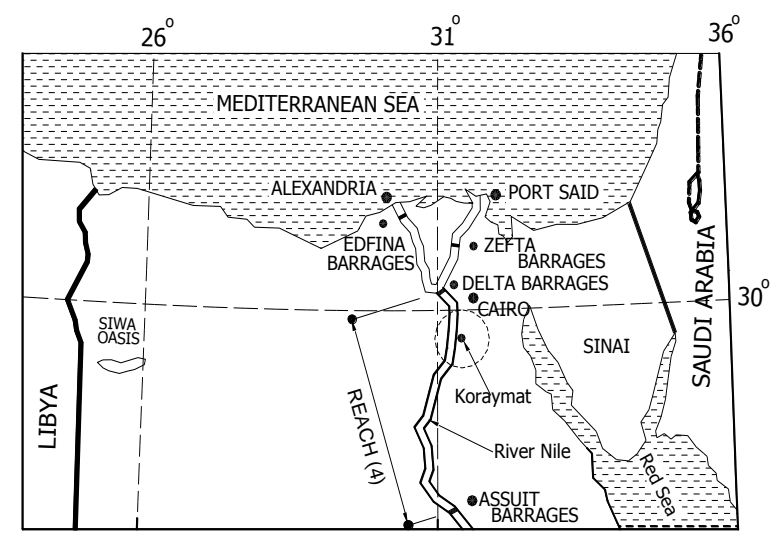

Fig. 8 - a: A River Nile map showing Koraymat current water intake site within a dashed circle.

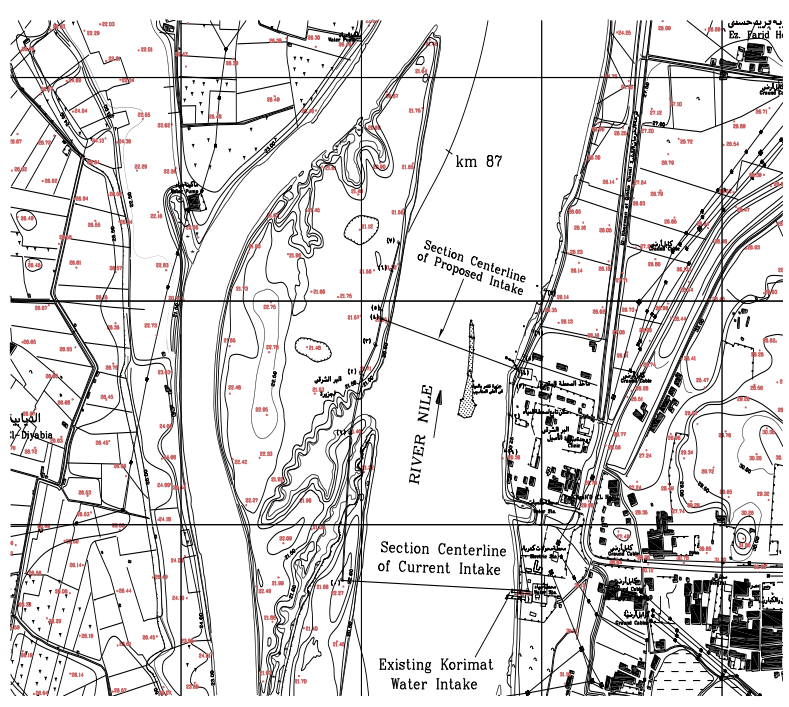

Fig. 8 - b: A topographic map showing the kilometer of the intake location.

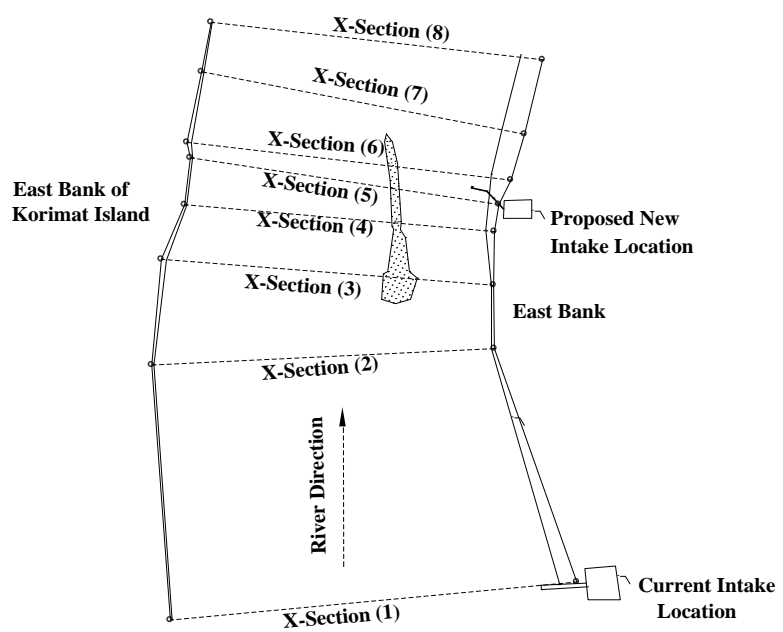

Fig. 8 - c: Cross sections bathymetrically surveyed at the current and proposed intake locations at Koraymat. 
Vol. 41, No.2. July 2022

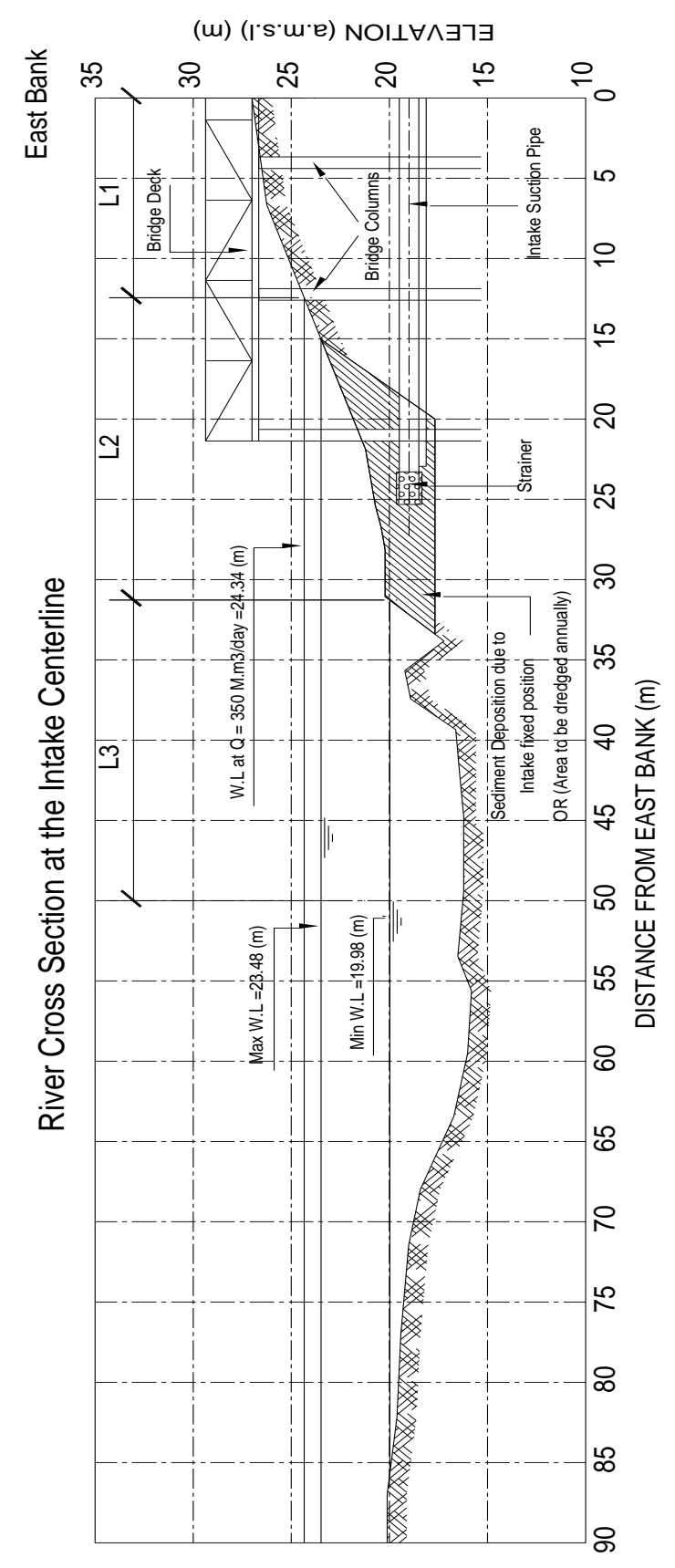

Fig. 9: Cross section (1) showing the annual sedimentation at Koraymat current intake location

\section{THE PROPOSED SOLUTION}

\subsection{Concept}

As mentioned before, the sediment accumulations at the intake suction pipe inlets had occurred due to the pipe inlet fixed position. If the inlets were initially designed and implemented to be unfixed and have the ability to freely reach out to different positions around the channel, sediment particles would never have a chance to accumulate. When there are no attraction or orientation forces acting on sediment particles over a long period of time, the particles are usually washed away or flushed easily in the flow direction. This always takes place, particularly during high water flow periods when flow velocities are higher and able to loosen and dismantle particle accumulations. Also, being unfixed and moveable, the pipe inlets can be submerged at points around the channel where clear water and big water depths are available. Accordingly, the proposed solution concept is intended to provide free movement to the intake pipe inlets such that they can be allowed to protract and retract and also swivel horizontally in a semi-circle. This can help access clearest water at multiple positions round the channel and avoid causing sediment depositions.

\subsection{Proposed Technology}

The use of tower crane technology as a pipecarrying intake structure is the only solution that can provide the free movement required to avoid and avert all the sedimentation and water recession problems. Changing the position of the pipe inlets will never happen until the suction pipes are carried on a movable crane boom (jib). This is because a crane is the only machine that can provide motion and rotation while carrying and transporting heavy loads. Hong and Shah [8] state that cranes have the capability of 


\section{Vol. 41, No.2. July 2022}

moving the load vertically up and down and in a horizontal plane either a long a straight or curved path. Therefore, a tower crane technology (an assembled structural truss system) can be employed as a movable intake structure that is able to carry the water suction pipes to abstract water from a wide area of an open channel permanently and safely.

According to Wikipedia Website [9], a crane is defined as a machine, equipped with a hoist, wire ropes or chains, and sheaves, that can be used both to lift and lower materials and to move them horizontally. Cranes are employed commonly in the transport industry for the loading and unloading of freight, in the construction industry for the movement of materials and in the manufacturing industry for the assembling of heavy equipment. Cranes could be classified into three main types; overhead, mobile, and fixed. Each can be tailored to a specific use.

\subsection{Assemblage and Operation Scheme}

The intake water suction pipes are to be carried on a crane lattice boom that has a sliding trolley running on inverted rails. This trolley has the ability to move the suction pipe inlets along the boom bottom in the offshore and landward directions. In our case study, the boom length shouldn't be less than $70 \mathrm{~m}$ according to the cross section bathymetry so that it can reach sufficient depths of water for ensuring permanent water abstraction as shown in Figs. $9 \& \mathbf{1 0}$. In addition, the boom can swivel horizontally in a semi-circle round a turntable resting on a pedestal. Also, it is connected to pendant cables that can be easily pulled (tightened) up or slackened using a pulley system. The pipe inlets are dangled and submerged into the channel to allow water abstraction. In this way, the inlets can move around the channel in a semi-circle of different radii taking up different positions.

It is worth mentioning that there are so many international crane construction companies that tailor and build structurally stable and reliable crane booms as required such as "Buckner Heavylift Cranes", "Techcrane International", "Uchimiya Transportation \& Engineering", etc. For more others, it can be referred to the internet website [10].

Therefore, it is proposed to tailor and build a fixed structural truss system platform on the riverside or bank having a high carryingcapacity lattice boom. The proposed structural system is to be composed of the following components as shown in Fig. 10:

1- A circular tower (mast) built of steel truss elements resting on and anchored to a steel truss platform with a turntable. The whole truss system is erected on a reinforced concrete raft foundation which, in turn, rests on a concrete pile cap for stability and equilibrium. On top of the tower, there is a system of pulleys fixed to a steel winch fixed on the ground behind the truss system landward. The pulleys are used for tightening up or slackening a set of hoisting pendant cables holding a lattice boom for ensuring stability and safety;

2- A supporting pyramidal truss pedestal round the tower and resting on and anchored to the raft foundation. The foundation level may be above or underground according to the river water stages and the boom height required above water surface. Also, the whole platform system may be established on the riverside or bank;

3- A steel turntable resting on a pedestal fixed to a pad anchored to the raft foundation. It should be designed so that 


\section{Vol. 41, No.2. July 2022}

it can revolve relative to the pad allowing the table to rotate horizontally;

4- A boom that can swivel horizontally round the turntable. The suction pipes are suspended to the boom bottom by suspenders. The pipes can be pulled forward and backward by means of the running trolley along the boom. Made of elastic material, the pipes are allowed be folded when empty of water round a drum fixed to the ground. This movement allows the hanging pipe inlets to be positioned at different distances offshore. Accordingly, the inlets can reach a large surface area of the open channel and avoid the places of potential sedimentation;

As shown in Fig. 10,

\section{The required boom total length}

$$
=\mathbf{L}_{1}+\mathbf{L}_{2}+\mathbf{L}_{3} \quad(\mathrm{~m})
$$

Where:

$\mathbf{L}_{\mathbf{1}}$ is the distance between the centerline of the circular tower and the shoreline during max or emergency water stage whichever is higher;

$\mathbf{L}_{\mathbf{2}}$ is the recession distance which is the distance between the shoreline in case of max or emergency water stage whichever is higher and that of the min water stages; and

$\mathbf{L}_{\mathbf{3}}$ is the distance from the shoreline during the min water stage to a depth enough to submerge the suction pipe inlet strainer and ensure permanent water abstraction. This depth depends on half of the maximum wave height (wave trough) likely in the study area, the strainer length, and the clearance above the channel bed. In general, it depends on the bed morphology and depth availability in the study area.

5- At the far end of the boom above the channel, suction pipes are hanging (dangling) down and submerged into water. There is also a possibility to drop an echo sounding transducer to measure the water depth to enable checking the bed aggradation (sediment accumulation) overtime. In addition, a sensor connected to a turbidimeter for measuring water turbidity can be dropped into water; and

6- A winch fixed and anchored to the concrete raft foundation built behind the platform (on the land side) having a pulley system with pendent cables connected to the pulley system fixed on top of the truss mast. It provides a counterbalance force to help stabilize the truss mast and the whole system. Also there is a counterweight at the back extension of the boom to balance the system.

\subsection{Feasibility Validation in Practice}

According to Guinness World Records [11], the heaviest weight lifted by a crane is 20133 tons $(44,385,667.25 \mathrm{lb})$ achieved by the 'Taisun' crane at Yantai Raffles Shipyard, Yantai, China on 18 April 2008. The object lifted was a barge, ballasted with water. Records change on a daily basis and are not immediately published online. According to this information, it is possible to tailor and build the proposed crane technology in practice. In our case study, the truss system platform can be structurally designed and constructed on the riverside or bank according to the structural design standard specification criteria for steel structures [12]. Also, the boom can be implemented applying the structural design standard criteria available in the literature and related to the required length, cross section dimensions, 


\section{Vol. 41, No.2. July 2022}

loads to be carried, truss system, steel materials, and many other mechanical and structural details which are out of the scope of this study. It is worthy of mentioning that this study only focuses on the river engineering standpoint, not the structural or mechanical design. However, it pays attention to the most important preliminary required data for tailoring and designing a lattice boom. They are the length, load, and inclination angle to the horizontal plane. For each designed and implemented lattice boom, there is a specific boom load capacity chart that explains the interrelationship between these three parameters [13].

\subsection{Approximate Calculation of Boom loads}

For the above case study,

- Assume that the vertical inclination angle $=0$ as it is a tower crane with a horizontal jib.

- The boom is required to be extended for a range of 50 to $60 \mathrm{~m}$ long to reach sufficient water depths according to the cross section bathymetry shown in Fig. 9. However, it is proposed to be $70 \mathrm{~m}$ with an increase buffer of $10 \mathrm{~m}$ more for future conditions. It is worth mentioning that a lattice boom length of $90 \mathrm{~m}$ has already been tailored and built by COMANSA, a crane manufacturing company [14];

- Assume that the boom proposed structural truss system is designed to carry a distributed weight (dead + live) of 3.20 tons per meter run and a moving load of 12 tons. The truss system design depends on the structural analysis of a suggested cross section and the material used. then,

The total weight of the boom $=3.20 * 70=$ 224 tons
The dead load $=$ the weight of the lattice boom structural system with all of its elements per meter run.

$$
=1.00 \mathrm{ton} / \mathrm{m}
$$

The live load $=$ people weight + wind + quake + weight of elastic pipes full of water.

$$
=0.40 \text { (for } 3 \text { persons) }+0.40+
$$

$0.40+1.00$ (3 elastic pipes filled with water of radius $300 \mathrm{~mm}$ for 2 or 3 shifts $)=2.20$ ton $/ \mathrm{m}$

The moving load $=12$ ton for the vertical dangling part of the suction pipes ( $9 \mathrm{~m}$ above the water surface and $3 \mathrm{~m}$ submergence) when the 3 pipes are full of water.

Weight of one meter length of full pipe $=$ $\pi *$ (pipe radius) $)^{2} *$ water density

$(22 / 7) *(0.3)^{\wedge} 2 * 1.00=0.283$ ton

Weight of one meter length of 3 full pipe $=0.283 * 3.0=0.85$ ton

For a dangling pipe length of $12.0 \mathrm{~m}$,

The moving load weight $=0.85 * 12.0=$ 10.20 ton, assume it as equal to 12 ton taking $18 \%$ as a factor of safety.

Obtaining these data, different companies round the world can be requested to tailor, design and build such a boom.

Comparing the length and loads of our case study boom to the already internationally implemented booms (see COMANSA and many others), it turns out that our tower crane proposal as a substitute solution for the current bridge-like intake is safely feasible and executable.

$\underline{\text { Where: }}$ 
Vol. 41, No.2. July 2022

\subsection{Application of the Proposed Solution}

Now, having the crane technology safely feasible worldwide, if it is applied at the site of our case study as a pilot project, dredging of about $14000 \mathrm{~m}^{3}$ of sediment accumulation will be avoided annually. Moreover, the intake will never suffer from sedimentation or water recession because of the continuous monitoring of the riverbed using the echo sounding transducer. Also, the water abstracted will be cleanest as it will be taken from optional clean places near the water surface due to using the turbidity sensor.

This truss system can be further replicated in other places within Egypt in the same way to serve other affected intake locations such as the ones in Fig. 7. Based on the bathymetric and hydrological data collected at these sites, here are the different boom lengths proposed as shown in Table 2 below. The weights and loads can be calculated as mentioned before.
Table 2: Proposed substitute crane technology and boom lengths for bridge intakes at some locations suffering sedimentation \& recession problems.

\begin{tabular}{|c|c|c|c|c|c|}
\hline \multirow[b]{2}{*}{ SN } & \multicolumn{4}{|c|}{ INTAKE DATA } & \multirow{2}{*}{$\begin{array}{c}\text { BOOM } \\
\text { LENGTH } \\
(\mathrm{m}) \\
\text { L1 + L2 + } \\
\quad \text { L3 }\end{array}$} \\
\hline & .0 & & 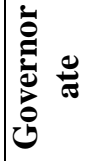 & 莺 & \\
\hline 1 & 駕 & $\begin{array}{l}\frac{0}{\bar{z}} \\
\stackrel{\bar{a}}{a}\end{array}$ & 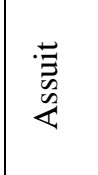 & $\frac{n}{i}$ & q \\
\hline 2 & 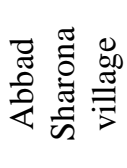 & $\begin{array}{l}\frac{0}{\vec{z}} \\
\stackrel{\overline{0}}{2}\end{array}$ & 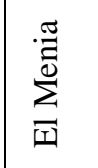 & $\stackrel{\circ}{\stackrel{\sigma}{r}}$ & 8 \\
\hline 3 & 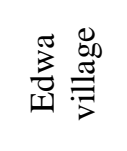 & 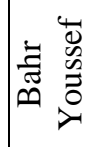 & 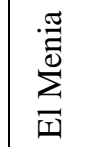 & $\stackrel{0}{\stackrel{\sim}{\sim}}$ & లి \\
\hline 4 & 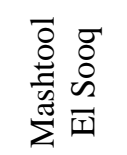 & Uี & 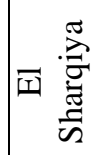 & 공 & 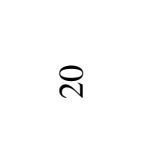 \\
\hline
\end{tabular}


Vol. 41, No.2. July 2022

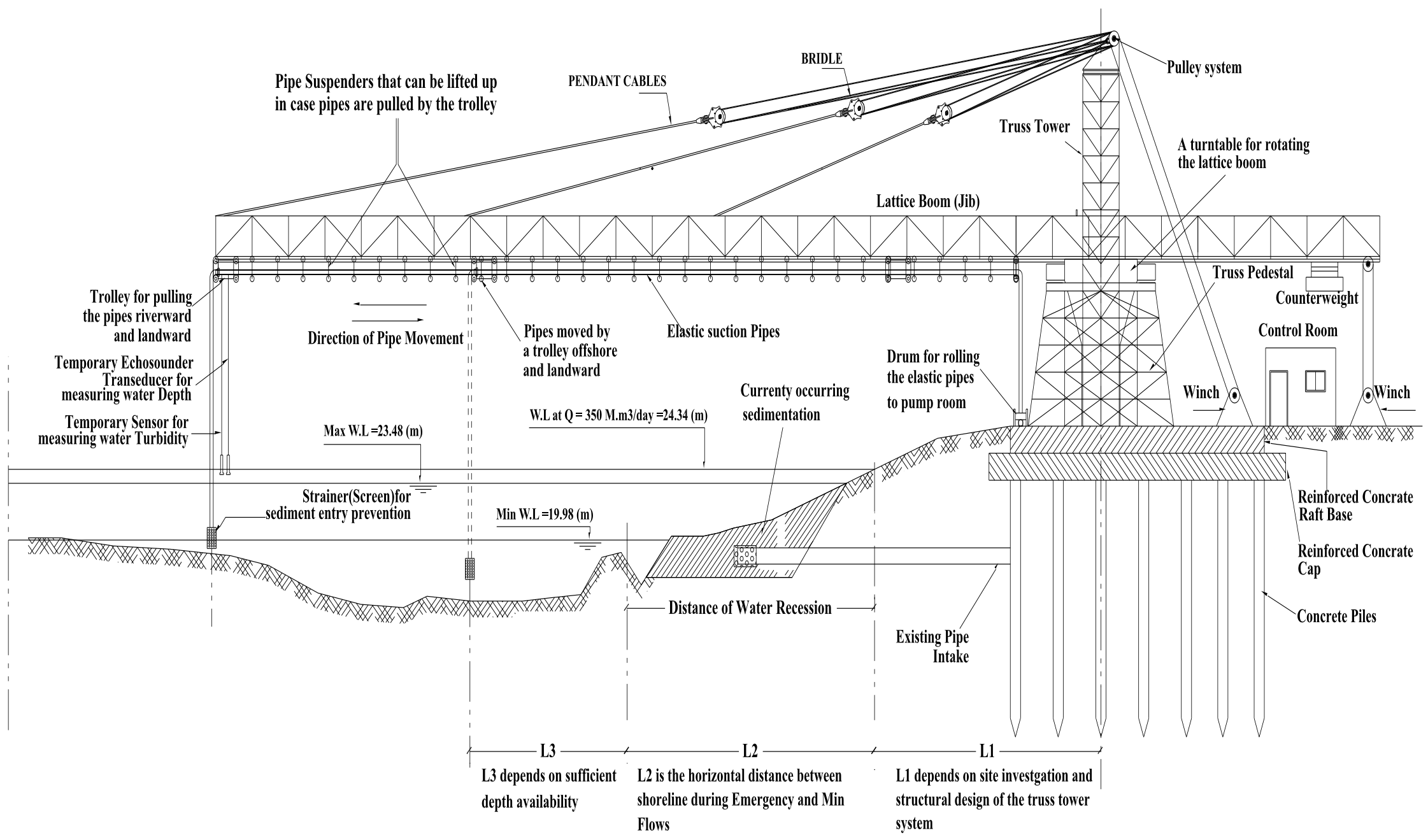

Fig. 10: A schematic proposed tower crane as a substitute for the current bridge-like water intake. 


\section{Vol. 41, No.2. July 2022}

\section{SUMMARY AND CONCLUSIONS}

The present research has thoroughly monitored the three problems facing the bridge-like intake currently applied along the River Nile in Egypt and found that they had turned to be a phenomenon not casespecific. These problems are sediment accumulation at the suction pipe inlet, river wide water recession, and consequent site unsuitability. A case study has been introduced to illustrate and clarify these problems. The study results revealed that the main reason for such problems is the fixed position of the bridge that carries the water abstraction pipes. Accordingly, a solution for overcoming the problems has been proposed. The concept lies in providing free movement to the intake pipe inlets such that they can be allowed to protract and retract and also swivel horizontally in a semi-circle. This can help access clearest water at multiple positions round the channel within the boom span and avoid causing sediment depositions that occur due to the fixed position of the bridge. It was found that this solution can only be accomplished by employing the available tower crane technology. This technology has been improving so amazingly and rapidly. It has become of high capabilities as far as the boom length and borne loads are concerned. It can replace the old intake bridge and carry the suction pipes successfully as it is already applied and proved reliable in different life aspects such as loading and unloading in ports and industry. Applying this technology as a substitute for the bridge will add new advantages as follows:

a. It will enable the suction pipe inlets to access and abstract water from a large area of the open channel as the boom allows pipe movement along its bottom. The problem of water recession during the low stage period will no longer exist; b. The heavy sediment accumulation round the suction pipe inlets of the bridge-like intake will no longer exist. The rates of sediment deposition at the inlets can be monitored using the echo sounding transducer. This helps to determine the suitable times at which the pipe inlet position can be changed to avoid any possible sediment accumulation;

c. By overcoming the sedimentation and water recession problems, the intake location will become more suitable since the site unsuitability is mostly caused by these two problems;

$\mathrm{d}$. This technology is fund-saving and environmentally friendly because it does not cause sediment accumulation that needs repetitive dredging work. Dredging requires more funding and affects the running cost of the intake on the one hand. On the other, it destroys the aquatic life and benthic ecosystems of the open channel; and

e. This technology will help ensure abstraction of water of good quality as it has the ability to reach out to channel positions of big depths that always provide water free from coarse sediment particles and impurities. Clear water causes neither pump damage nor erosion of piping.

\section{RECOMMENDATIONS}

- The crane technology should be first applied as a pilot project along the River Nile before it can be generalized;

- International giant crane companies should be consulted to tailor and build safe and economic cranes that can be used as water intake structures in different practical cases. 


\section{Vol. 41, No.2. July 2022}

\section{References}

[1] Brikké, F. Bredero, M (2003), "Linking Technology Choice with Operation and Maintenance in the Context of Community Water Supply and Sanitation", Chapter 1, World Health Organization and IRC Water and Sanitation Centre, Geneva, Switzerland.

[2] Lauterjung, H. and Schmidt, G. (1989), "Planning of intake structures". Braunschweig, Vieweg.

[3] Jordan, T.D. (1984), "A handbook of gravityflow water systems for small communities", London, Intermediate Technology Publications.

[4] Hofkes, E. H. and Visscher JT (1986), "Renewable energy sources for rural water supply", the Hague, IRC International Water and Sanitation Centre (Technical Paper Series, No. 23).

[5] Bosman, D. E. et al. (2002), "An investigation into the removal of sediments from water intakes on rivers by means of jet-type dredge pumps", WRC Technical Report No. 1187/1/02, April, 2002.

[6] Nasr Hekal (2015), "Effect of Water Surface Recession on Bridge-Type Intakes Proposed along the River Nile". The International Water Technology J. 5. 4, pp. 272- 283.

[7] NRI (2014), "Studying the Proposal of Changing the Location of Koraymat Current Drinking Water Intake", Report No 1148, January, 2014, NRI Library.

[8] K. -S. Hong and U. H. Shah (2019), "An ebook of Dynamics and Control of Industrial Cranes", Chapter 1, Springer Nature Singapore, Pte Ltd. 2019.

[9] Wikipedia (2020), "En.wikipedia.org/wiki /crane_(machine)". (Accessed March 10 2020)

[10]"http://www.Constructionreviewonline.com/ 2014/06/top-20-worlds-largest-cranecompanies".

[11]"http://www.GUINNESSWORLDRECORDS. com/world-records/heaviest-weight-liftedby-a-crane". (Accessed Feb., $1^{\text {st }} 2015$ )

[12] ANSI/AISC 360-16, (2016), "Specification for Structural Steel Buildings", an American National Standard, July, 2016. [13]"https://www.utilitycontractoronline.com/un derstanding-load-charts/".(Accessed March $\left.1^{\text {st }}, 2020\right)$

[14]"https://cranemag.com/crane-business/ companies/comansa-upgrades-models21lc660-and-21lc750/". (Accessed April 1 ${ }^{\text {st }}$, 2020)

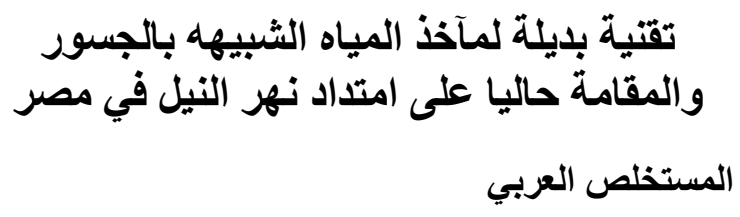

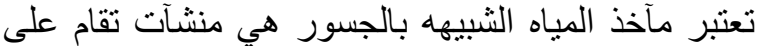

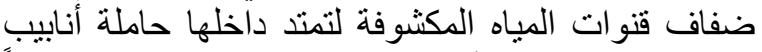
سحب للوصول إلى أعماق كافية من المياه تضمن التمن سحباً

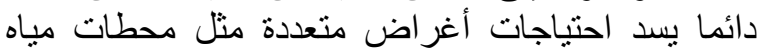

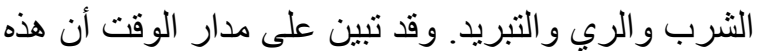

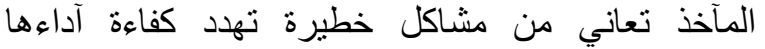

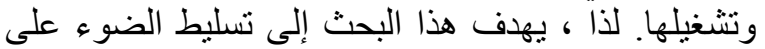
هذه المشاكل ، وتقديم تقنية جديدة لهذه المآخذ كحل بديل.

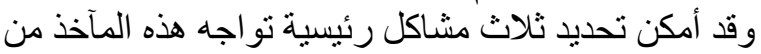

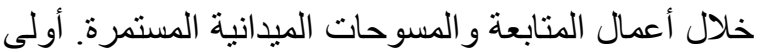

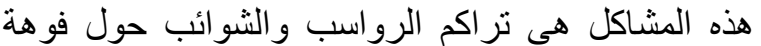
أنبوب السحب ، الأمر الذي يؤدي إلى الذى سد فتحات مصفاة (فانوس) الفوهة و إعاقة سحب المبر المياه أو منعها تماميا. ثانيها هي انحسار ونر اجع سطح المياه الناعة الناتج عن الدورة السنوية

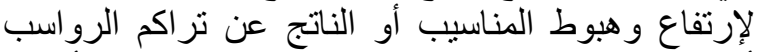

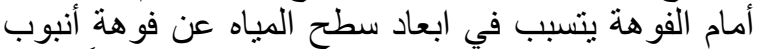

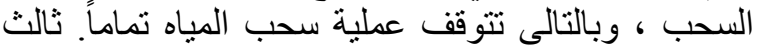

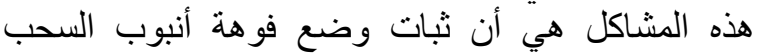
ينسبب في تفاقم وتعجيل حدوث المثات المشكلنين الأوليين.

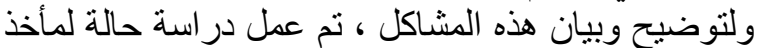

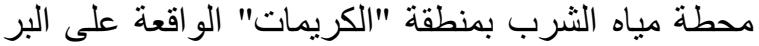
الثرقي لنهر النيل جنوب القاهرة. وقد تبين من الدر اسة أن الن الني

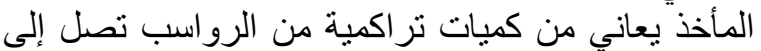

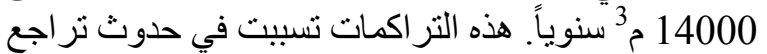

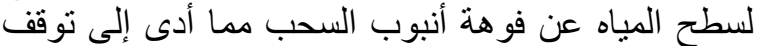

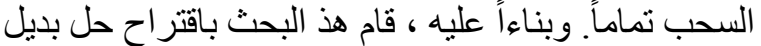

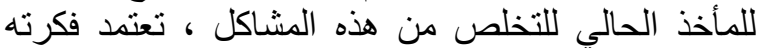

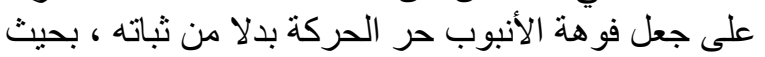

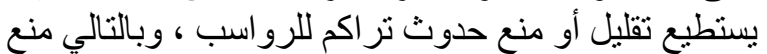
حدوث تراجع لسطح المياه. وقد تبين من البحت البحث أن التئنية الوحيدة والمتاحة حاليا و التي يمكن أن تحقق لتحن هذه الفكرة هي تقنية الروافع البرجية. 